\title{
Melatonin Improves Heat Tolerance in Kiwifruit Seedlings through Promoting Antioxidant Enzymatic Activity and Glutathione S-Transferase Transcription
}

\author{
Dong Liang ${ }^{1,2,+} \mathbb{C}^{\mathbb{D}}$, Fan Gao ${ }^{1,+}$, Zhiyou Ni ${ }^{1}$, Lijin Lin ${ }^{1,2}$, Qunxian Deng ${ }^{1}$, Yi Tang ${ }^{1,2}$, \\ Xun Wang ${ }^{1,2}$, Xian Luo ${ }^{1}$ and Hui Xia ${ }^{1,2, *}$ \\ 1 College of Horticulture, Sichuan Agricultural University, Chengdu 611130, China; \\ liangeast@sicau.edu.cn (D.L.); 18227551150@163.com (F.G.); nizhiyou123@sina.com (Z.N.); \\ 1lj800924@163.com (L.L.); dqxlwj@sina.com (Q.D.); tangyisunguochao@sina.com (Y.T.); \\ wangxun0104@hotmail.com (X.W.); lawxian@aliyun.com (X.L.) \\ 2 Institute of Pomology and Olericulture, Sichuan Agricultural University, Chengdu 611130, China \\ * Correspondence: susanxia_2001@163.com; Tel.: +86-28-8629-1136 \\ + These authors contributed equally to this work.
}

Received: 29 January 2018; Accepted: 1 March 2018; Published: 6 March 2018

\begin{abstract}
Evidence exists to suggest that melatonin (MT) is important to abiotic stress tolerance in plants. Here, we investigated whether exogenous MT reduces heat damage on biological parameters and gene expression in kiwifruit (Actinidia deliciosa) seedlings. Pretreatment with MT alleviates heat-induced oxidative harm through reducing $\mathrm{H}_{2} \mathrm{O}_{2}$ content and increasing proline content. Moreover, MT application raised ascorbic acid (AsA) levels and the activity of antioxidant enzymes, including superoxide dismutase (SOD), catalase (CAT), and peroxidase (POD). We also observed elevation in the activity of enzymes related to the AsA-GSH cycle, such as ascorbate peroxidase (APX), monodehydroascorbate reductase (MDHAR), dehydroascorbate reductase (DHAR), and glutathione reductase (GR). Furthermore, MT application increased the expression of 28/31 glutathione S-transferase (GST) genes, reducing oxidative stress. These results clearly indicate that in kiwifruit, MT exerts a protective effect against heat-related damage through regulating antioxidant pathways.
\end{abstract}

Keywords: antioxidant enzymes; glutathione S-transferase; kiwifruit; melatonin; high temperature stress

\section{Introduction}

Temperatures $5{ }^{\circ} \mathrm{C}$ above optimal growing conditions induces heat shock or stress in plants, causing growth inhibition and crop failure [1,2]. These negative effects occur because cellular homeostasis is disrupted through mass formation of reactive oxygen species (ROS) in plant cells. These compounds include singlet oxygen $\left({ }^{1} \mathrm{O}_{2}\right)$, superoxide radical $\left(\mathrm{O}_{2}{ }^{\bullet-}\right)$, hydrogen peroxide $\left(\mathrm{H}_{2} \mathrm{O}_{2}\right)$, and hydroxyl radical $\left(\mathrm{OH}^{\bullet}\right)$ are responsible for oxidative stress [3]. As a result, lipid peroxidation increases to cause oxidative stress, damaging membrane protein polymerization and cross-linking, as well as lowering membrane mobility, permeability, and thermal stability [4,5]. Like other aerobic organisms [6], plants have evolved defense systems that are well equipped with different antioxidant components to scavenge over-produced ROS, thus protecting plants from oxidative injury. An important aspect of these systems are antioxidant enzymes such as superoxide dismutase (SOD), catalase (CAT), peroxidase (POD), ascorbate peroxidase (APX), glutathione reductase (GR), monodehydroascorbate reductase (MDHAR), and dehydroascorbate (DHAR), as well as non-enzyme antioxidants such as ascorbic acid (AsA) and glutathione (GSH) [7,8]. In particular, glutathione S-transferases (EC 2.5.1.18) are a diverse, multifunctional group of stress-response enzymes, catalyzing GSH-dependent peroxidase reactions that scavenge toxic organic hydroperoxides. According to the 
genetic structure and protein homology, plant GSTs can be divided into 6 categories: Phi, Tau, Zeta, Lambda, Theta and Dehydroascorbate reductases (DHAR) [9,10].

Melatonin (MT) has received much recent attention in plant research because of its role as a growth regulator and a biostimulator for stress resistance [11]. The molecule enhances photosystem (PS) II activity [12]; alleviates growth inhibition and leaf senescence [13]; improves germination percentage [14], raise antioxidative enzymatic activity, antioxidant content [15,16]; and nitrogen metabolic enzyme activity [17]; as well as improve overall growth and rooting [18].

Kiwifruit (Actinidia deliciosa) is a perennial vine that is commercially cultivated in China, New Zealand, Chile, Japan, and Italy. Its heat-sensitivity is a major obstacle to crop productivity, however [19]. Long-term high temperatures cause flower and fruit dropping, quality deterioration, and storage decline [20]. Although a few studies on kiwifruit heat resistance are available [21,22], few researchers have examined how exogenous MT applications may improve antioxidation systems in kiwifruit seedlings under heat stress. Thus, the present study investigated the effectiveness of exogenous MT as an antioxidant-pathway regulator and an enhancer of heat-stress tolerance in kiwifruit.

\section{Results}

\subsection{Seedling Morphology, $\mathrm{H}_{2} \mathrm{O}_{2}$ and Proline Content in Heat-Stressed Kiwifruit}

Before the experiment, seedlings were nearly identical across all three treatments (control $\left[\mathrm{CK}, 25^{\circ} \mathrm{C}\right]$, high-temperature $\left[\mathrm{HT}, 45^{\circ} \mathrm{C}\right.$, melatonin-pretreated high-temperature [MTHT, $45^{\circ} \mathrm{C}$ ) (Figure 1A). After $8 \mathrm{~h}$ treatment, HT seedlings exhibited dried leaves and water loss, whereas the MTHT group showed significantly fewer heat-stress symptoms (Figure 1A).

(A)

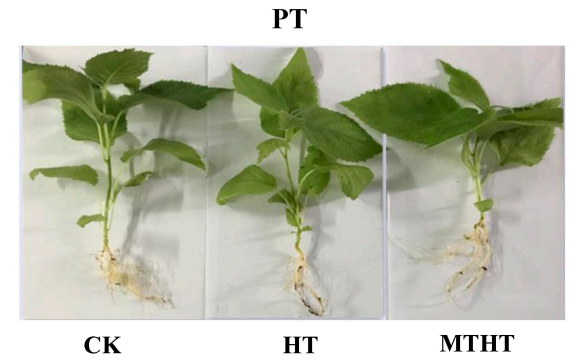

(B)

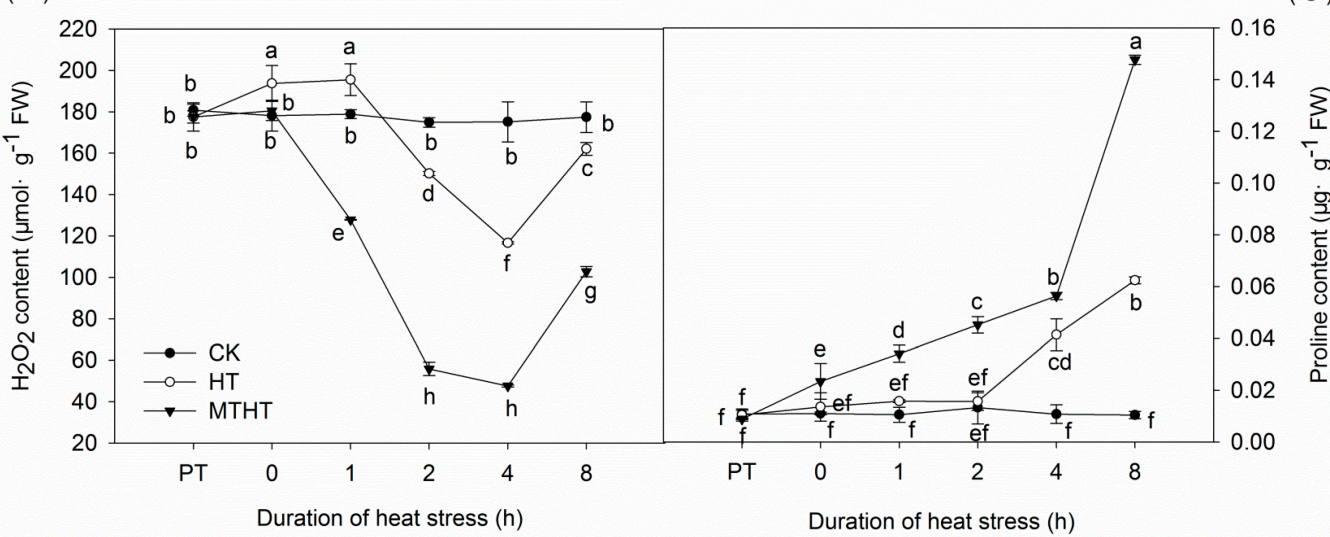

$8 \mathrm{~h}$

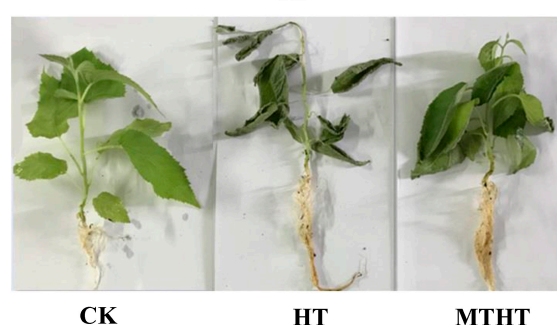

C)

Figure 1. (A) Seedling morphology at $\mathrm{PT}\left(25^{\circ} \mathrm{C}\right.$ starting temperature $)$ and after $8 \mathrm{~h}$ at $45^{\circ} \mathrm{C} ;(\mathbf{B}) \mathrm{H}_{2} \mathrm{O}_{2}$ content in leaves under heat stress; (C) Proline content in leaves under heat stress. CK, control; HT, high temperature treatment $\left(45^{\circ} \mathrm{C}\right)$; melatonin-pretreated high-temperature (MTHT), high temperature with melatonin pre-treatment. Data are means of three biological replicates $(n=3)$. Lowercase letters indicate significant differences $(p<0.05)$. 
Under the first $2 \mathrm{~h}$ of $\mathrm{HT}, \mathrm{H}_{2} \mathrm{O}_{2}$ content in kiwifruit seedling increased, but then rapidly decreased until $4 \mathrm{~h}$ of HT (Figure 1B). Notably, MTHT seedlings had significantly lower $\mathrm{H}_{2} \mathrm{O}_{2}$ levels than HT seedlings.

Proline prevents plant cell dehydration and protects cytoplasmic membrane integrity. In HT and MTHT kiwifruits, proline content gradually increased over time (Figure 1C), but by $8 \mathrm{~h}$, MTHT seedlings contained 1.36 and 2.1 times more proline than CK and HT seedlings, respectively.

\subsection{POD, CAT, and SOD Activities under Heat Stress}

We observed a significant increase in POD activity that peaked at $1727.4 \mathrm{U} \cdot \mathrm{g}^{-1} \cdot \mathrm{min}^{-1} \mathrm{FW}$ after $1 \mathrm{~h}$ of HT, before falling to CK levels after $4 \mathrm{~h}$. Additionally, MT pretreatment dramatically increased POD activity, peaking after $1 \mathrm{~h}$ at $3360 \mathrm{U} \cdot \mathrm{g}^{-1} \cdot \mathrm{min}^{-1} \mathrm{FW}$, over two times greater than activity in HT leaves. After a drop at $2 \mathrm{~h}$, POD activity in MTHT seedlings continued to increase (Figure 2A).

We recorded a persistent increase in CAT activity under heat stress, peaking at $2 \mathrm{~h}$ of treatment (HT: $17.35 \mathrm{U} \cdot \mathrm{g}^{-1} \cdot \mathrm{min}^{-1} \mathrm{FW}, \mathrm{MTHT}: 24.06 \mathrm{U} \cdot \mathrm{g}^{-1} \cdot \mathrm{min}^{-1} \mathrm{FW}$ ) (Figure $2 \mathrm{~B}$ ). Subsequently, CAT activity decreased in both MTHT and HT seedlings. Throughout the experiment, CAT activity was significantly higher in MTHT than in HT.

Heat stress immediately (at $0 \mathrm{~h}$ ) caused a marked and rapid decrease of $20.31 \%$ in SOD activity among HT leaves compared with CK leaves (Figure 2C). This decline was halved in MTHT leaves.

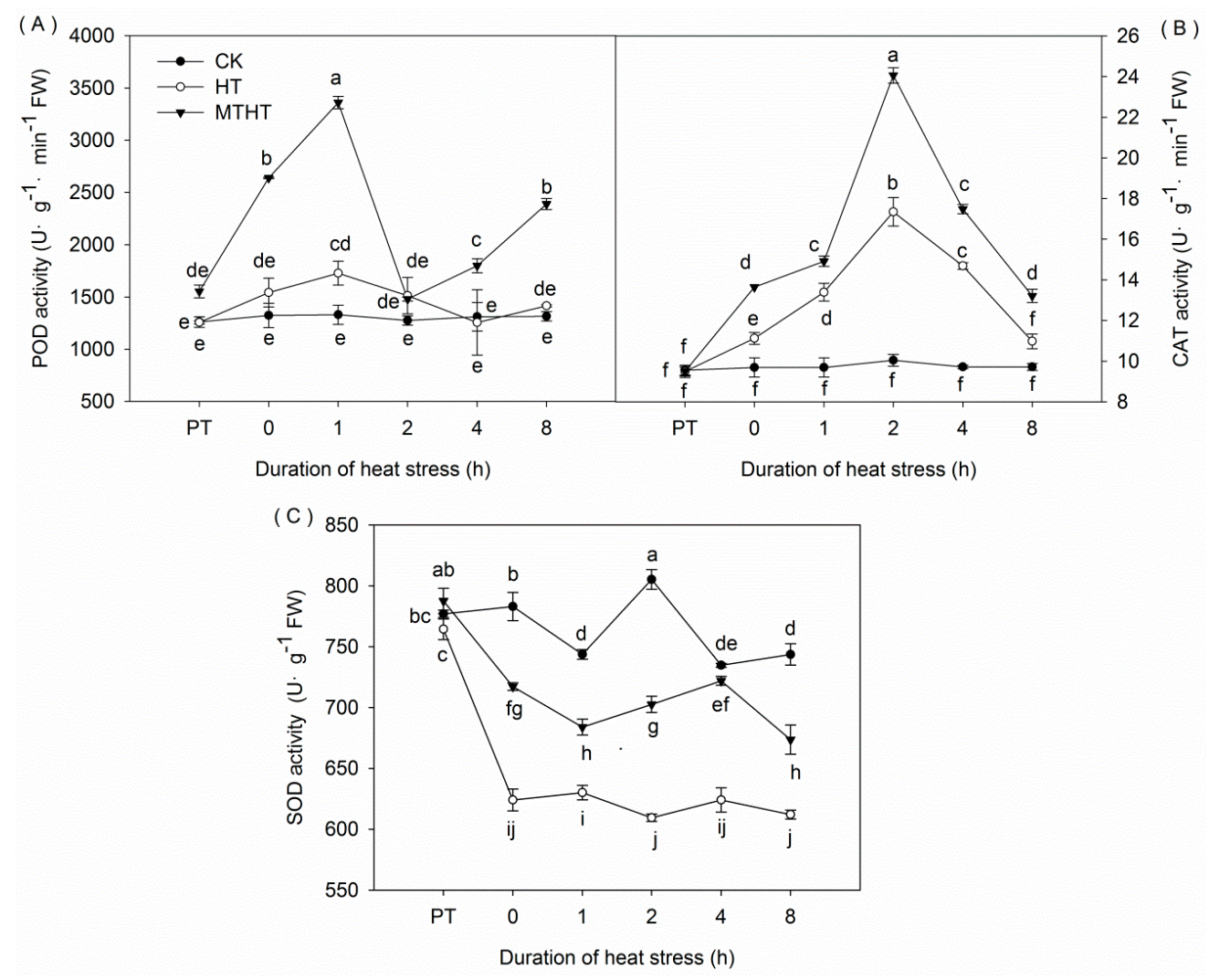

Figure 2. Antioxidant enzyme activity under heat stress. (A) Peroxidase (POD); (B) catalase (CAT); and $(\mathrm{C})$ superoxide dismutase (SOD). Lowercase letters indicate significant differences $(p<0.05)$.

\subsection{Ascorbic Acid Content and AsA-GSH-Cycle Enzymatic Activity under Heat Stress}

Compared with the steady levels in CK, AsA content exhibited two peaks in both HT and MTHT (Figure 3). In MTHT, AsA peaked at $1 \mathrm{~h}$, reaching a value that was 19.19\% greater than corresponding values in HT. Overall, except at $0 \mathrm{~h}$, MTHT seedlings had higher AsA content than HT seedlings. 
Under heat stress, APX activity in HT increased steadily until $4 \mathrm{~h}$, when activity began to fluctuate slightly. In contrast, APX activity in MTHT persistently increased over time, peaking at $8 \mathrm{~h}$ with $3.32 \mathrm{U} \cdot \mathrm{g}^{-1} \cdot \mathrm{min}^{-1} \mathrm{FW}$, twice as high as corresponding HT values (Figure $4 \mathrm{~A}$ ). Heat stress also increased MDHAR activity, most noticeably in MTHT. In these leaves, enzyme levels exhibited a wavelike pattern that peaked at $5.76 \mathrm{U} \cdot \mathrm{g}^{-1} \cdot \mathrm{min}^{-1} \mathrm{FW}$ after $8 \mathrm{~h}$, a $193.31 \%$ increase from levels at $0 \mathrm{~h}$ (Figure 4B). In both HT and MTHT, DHAR activity first rose steadily beyond CK levels, before decreasing after $2 \mathrm{~h}$. At the $2 \mathrm{~h}$ peak level, DHAR activity in MTHT was 20.85\% higher than in HT, and both values were higher than CK. (Figure 4C). Finally, GR activity in HT significantly increased, peaking at $2 \mathrm{~h}\left(2.18 \mathrm{U} \cdot \mathrm{g}^{-1} \cdot \mathrm{min}^{-1} \mathrm{FW}\right)$ before decreasing. In contrast, GR activity rose continuously in MTHT, increasing by $143.89 \%$ at $8 \mathrm{~h}$ (Figure $4 \mathrm{D}$ ).

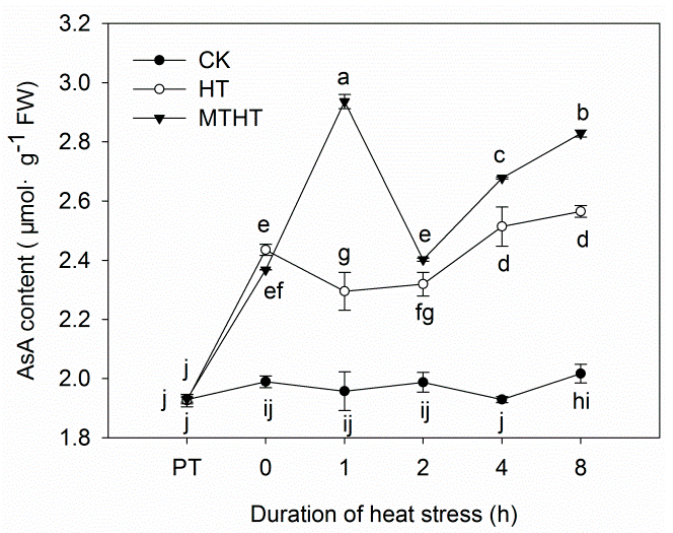

Figure 3. Ascorbic acid (AsA) content in kiwi leaves under heat stress. Lowercase letters indicate significant differences $(p<0.05)$.
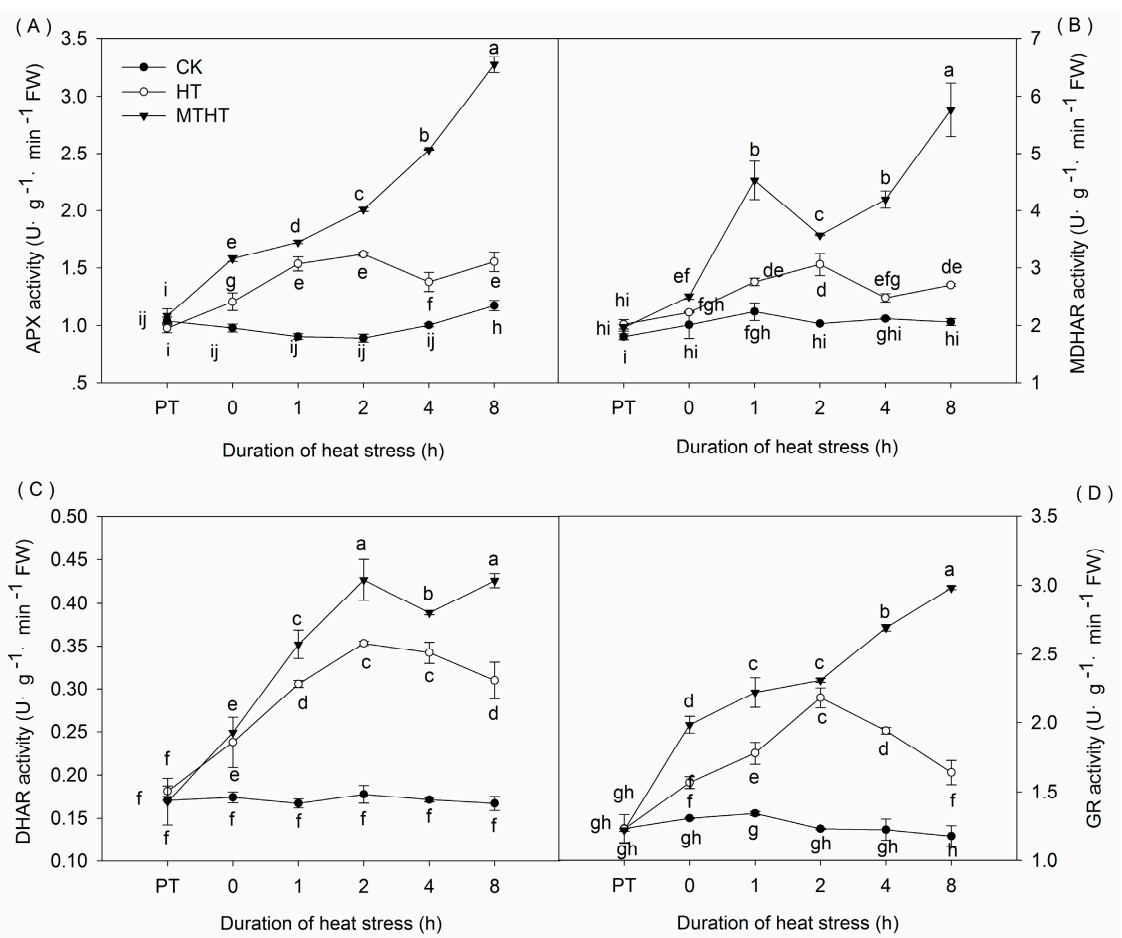

Figure 4. Activity of key enzymes from the AsA-GSH cycle in heat-stressed kiwi leaves. (A) Ascorbate peroxidase (APX); (B) monodehydroascorbate reductase (MDHAR); (C) dehydroascorbate (DHAR); and (D) glutathione reductase (GR). Lowercase letters indicate significant differences $(p<0.05)$. 


\subsection{Expression Profile of GST under Heat Stress}

Using RNA-seq data, we discovered GST gene expression patterns differed significantly between MTHT and HT (adjusted $p<0.05$; Figure 5A). There were 25 Tau GSTs, 2 Lambda GSTs, 2 Theta GSTs, 1 Phi GST and 1 unknown GST. The 31 differentially expressed GST genes were classified in five groups based on their deviation from CK expression level. (1) GST was down-regulated in HT and up-regulated in MTHT (12 transcripts); (2) GST was up-regulated in both HT and MTHT (11 transcripts); (3) GST remained unchanged in HT and up-regulated in MTHT (5 transcripts); (4) GST was up-regulated in HT and down-regulated in MTHT (2 transcripts); (5) Finally, GST was down-regulated in HT and MTHT (1 transcript). Overall, MT significantly up-regulated 28 GST genes, and only down-regulated 3.

Next, we selected GST25 (ACHN160841) in Group 2 for quantitative real-time PCR (qRT-PCR) analysis, to understand how GST expression changed over time (Figure 5B). Compared with CK, GST expression in HT first increased and then decreased. Additionally, GST gene expression in MTHT increased by $439.36 \%, 539.09 \%$, and $495.04 \%$ at 0,4 , and 8 h, respectively, compared with HT (Figure 5).

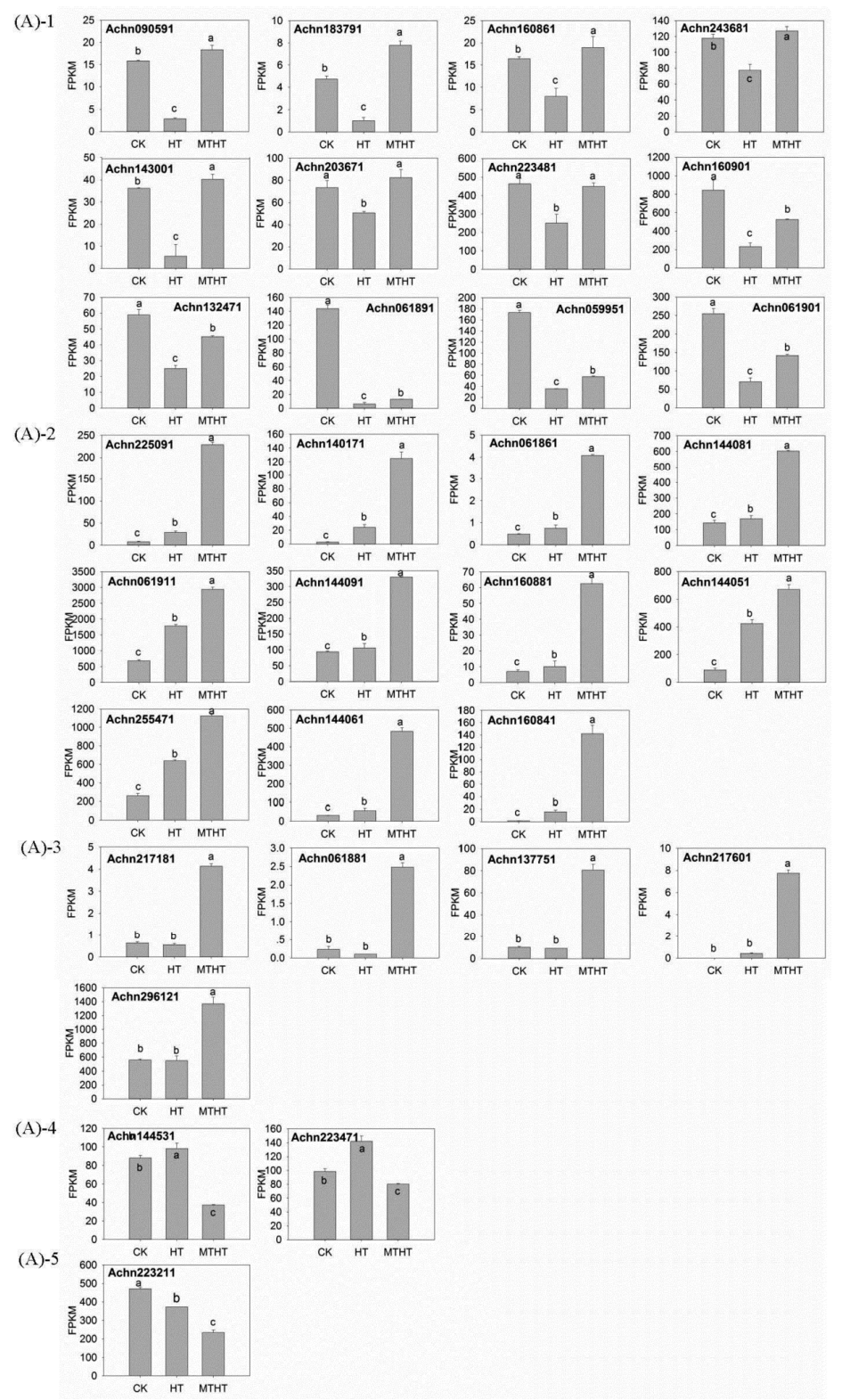

Figure 5. Cont. 


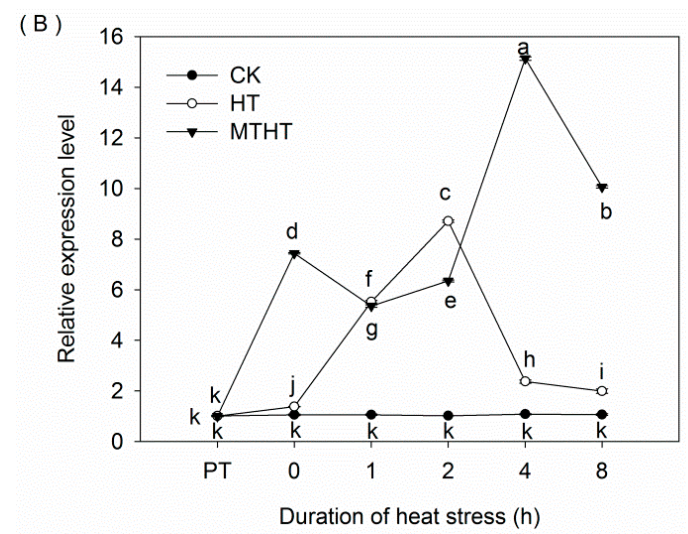

Figure 5. (A) Results of RNA-seq showing significant differences in GST gene expression between MTHT and HT; (B) Data from qRT-PCR showing GST25 (ACHN160841 expression profile under heat stress. Lowercase letters indicate significant differences $(p<0.05)$.

\section{Discussion}

Melatonin is a well-documented antioxidant in plants that is critical to alleviating environmental stress [23-26]. Here, we observed that one key way exogenous MT increased kiwifruit heat resistance was through decreasing $\mathrm{H}_{2} \mathrm{O}_{2}$ content, in accordance with other work on Malus, Cynodon dactylon, and cucumber [27-29]. The mechanism underlying $\mathrm{H}_{2} \mathrm{O}_{2}$ reduction is likely the fact that MT acts as an electron donor [24]. Additionally, SOD catalyzes the removal of $\mathrm{O}_{2}{ }^{\bullet-}$ by dismutating it into $\mathrm{O}_{2}$ and $\mathrm{H}_{2} \mathrm{O}_{2}$ [30]; $\mathrm{CAT}$ and POD are involved in scavenging $\mathrm{H}_{2} \mathrm{O}_{2}$ to $\mathrm{H}_{2} \mathrm{O}$ and $\mathrm{O}_{2}$ [31]. In our study, we found $\mathrm{H}_{2} \mathrm{O}_{2}$ content in $\mathrm{HT}$ is lower than in $\mathrm{CK}$, which may be because of the SOD reduction activity was not enough to counteract the occurring oxidative load. We, observed that under heat stress, MT enhanced the activity of major antioxidant enzymes (SOD, CAT, POD), possibly through upregulation of relevant genes. These results are similar to findings in cold-stressed cucumber and pepper seeds, showing that MT increased SOD activity through various physiological and molecular mechanisms in response to decreased $\mathrm{H}_{2} \mathrm{O}_{2}[15,16]$. Likewise, our data correspond to results of MT treatment on stressed tea [32] and wheat [33]. Furthermore, as observed in wheat seedling [34,35], we found that heat stress increased proline content in kiwi leaves, perhaps because stress abolished feedback inhibition in the proline biosynthetic pathway [36]. Furthermore, MT pretreatment magnified this increase, as reported in cherry [37] and tomatoes [38]. These patterns may be attributable to the maintenance of low cell osmotic potential and reduced water loss through MT-induced proline accumulation, allowing improved adaption to a hot environment $[39,40]$.

In our study, exogenous MT increased AsA content through elevating MDHAR and DHAR activity. Moreover, MT treatment increased GR activity more than it increased DHAR activity. These compounds are all part of the AsA-GSH cycle, an important antioxidant pathway that generates the small-molecule, non-enzymatic antioxidants AsA and GSH [41]. Fluctuation in AsA content is dependent on APX, MDHAR, and DHAR activities, with the latter two responsible for recycling AsA. Additionally, DHAR oxidizes GSH to GSSG during ROS scavenging, while GR recycles GSH. Our data thus suggest that exogenous MT is important to AsA and GSH biosynthesis/regeneration. Overall, we demonstrated that enhancing the AsA-GSH cycle is another way exogenous MT can protect plant tissues from oxidative damage [42,43].

Finally, we discovered 31 differentially expressed GST genes between MTHT and HT kiwifruit. They had five expression patterns which may be due to different functions of the gene family $[9,44]$. Glutathione S-transferases are critical to plant development and stress response through their scavenging of peroxides and other electrophiles [45-50]. Indeed, GST over-expression improves abiotic stress tolerance in tobacco and Arabidopsis [51,52]. The fact that we observed more up-regulated than down-regulated genes suggest that MT may dramatically decrease free-radical production and improve plant heat tolerance 
through elevating GST transcript abundance [53,54]. In general, our results proved that MT can improve the heat tolerance of heat-sensitive plants, moreover provided a way to make heat-sensitive plants grow better under heat stress.

\section{Materials and Methods}

\subsection{Plant Materials and Treatment}

Kiwifruit seeds were first disinfected for $5 \mathrm{~min}$ using 5\% sodium hypochlorite and rinsed with distilled water. Cleaned seeds were grown at $4{ }^{\circ} \mathrm{C}$ and $60-70 \%$ relative humidity for 60 days. After a week-long poikilothermic treatment at $4{ }^{\circ} \mathrm{C}$ for $10 \mathrm{~h}$ and $25{ }^{\circ} \mathrm{C}$ for $14 \mathrm{~h}$, germinated seeds were planted in plastic pots (diameter: $18 \mathrm{~cm}$; height: $23 \mathrm{~cm}$ ) filled with sand. They were then moved to a phytotron at Sichuan Agricultural University, Chengdu, China ( $30^{\circ} 42^{\prime} \mathrm{N}, 103^{\circ} 51^{\prime} \mathrm{E}$ ), under conditions of $25 / 20^{\circ} \mathrm{C}$ (day/night) and a 12/12 h (day/night) photoperiod. At the two-true-leaf stage, seedlings were watered in 2 days intervals with 1/2 Hoagland's nutrient solution (pH adjusted to $6.5 \pm 0.1$ with diluted $\mathrm{HCl}$ or $\mathrm{NaOH})$.

Treatments began at the 10 -true-leaf stage. First, CK plants were maintained at $25^{\circ} \mathrm{C}$ throughout the entire experiment. Second, HT seedlings were transferred to an incubator that increased from $25^{\circ} \mathrm{C}$ to $45^{\circ} \mathrm{C}$ across $2 \mathrm{~h}$, and then maintained at the latter temperature for $8 \mathrm{~h}$. Third, MTHT seedlings were pretreated 5 times with $200 \mu \mathrm{M}$ MT solution, every two days, and then subjected to the same conditions as HT plants. Each treatment was performed in triplicate. The moment when the incubator temperature at $25^{\circ} \mathrm{C}$, was designed as PT; the moment when the incubator temperature just reached at $45^{\circ} \mathrm{C}$, was designed as $0 \mathrm{~h}$. Five to eight middle leaves per plant were sampled at PT, $0,1,2,4$, and $8 \mathrm{~h}$. All collected tissues were immediately frozen in liquid nitrogen and stored at $-80{ }^{\circ} \mathrm{C}$.

\subsection{Assays of $\mathrm{H}_{2} \mathrm{O}_{2}$ Content and Antioxidant Enzyme Activity}

Determination of $\mathrm{H}_{2} \mathrm{O}_{2}$ and proline levels followed previously described methods [55,56].

The photochemical reduction of NBT [57] was used to assay SOD activity. The guaiacol colorimetric method [58] was employed for measuring POD activity. Finally, CAT activity was calculated as the decline in A240 [59].

\subsection{Extraction and Assay of AsA Content and AsA-GSH Cycle Enzymes}

Ascorbic acid content was measured following existing methods [60]. Briefly, leaves (0.3 g) were ground in a prechilled mortar, then homogenized in $5 \mathrm{~mL}$ of ice-cold $6 \%(v / v)$ trichloroacetic acid (TCA) and $1 \mathrm{mM}$ EDTA- Na2 solution. Crude extract was centrifuged at $2{ }^{\circ} \mathrm{C}$ and $12,000 \mathrm{~g}$ for $10 \mathrm{~min}$; the supernatant was collected for analysis. We neutralized $50 \mu \mathrm{L}$ extract with $250 \mu \mathrm{L} 10 \%(w / v)$ TCA, $200 \mu \mathrm{L} 42 \% \mathrm{H}_{3} \mathrm{PO}_{4}$, and $200 \mu \mathrm{L} \%(w / v)$ 2,2-Dipyridyl $\left(\mathrm{C}_{10} \mathrm{H}_{8} \mathrm{~N}_{2}\right)$. The assay was performed using a spectrophotometer at $525 \mathrm{~nm}$ in $200 \mathrm{~mm}$ sodium phosphate buffer (pH 7.4), both before and after a 60 min incubation at $42{ }^{\circ} \mathrm{C}$ with $100 \mu \mathrm{L}$ of $3 \%(w / v) \mathrm{FeCl}_{3}$.

To determine the activity of enzymes involved in the AsA-GSH cycle, leaves $(0.5 \mathrm{~g})$ were ground in a chilled mortar with $4 \%(w / v)$ polyvinylpolypyrrolidone, then homogenized with $8 \mathrm{~mL}$ of $50 \mathrm{mM}$ potassium phosphate buffer ( $\mathrm{pH} 7.5$ ) containing $1 \mathrm{mM}$ EDTA-Na 2 and $0.3 \%$ Triton $\mathrm{X}-100$. The activity of APX was determined via monitoring absorbance decreases at $290 \mathrm{~nm}$ as reduced $\mathrm{H}_{2} \mathrm{O}_{2}$ was oxidized [61]. Similarly, MDHAR activity was assayed through monitoring absorbance decreases at $340 \mathrm{~nm}$ as NADH was oxidized [62]. Next, DHAR activity was determined through absorbance increases at $265 \mathrm{~nm}$ due to dehydroascorbate (DHA) formation [61]. Finally, GR activity was assayed through absorbance decreases at $340 \mathrm{~nm}$ from NADPH oxidation [63].

\subsection{Quantitative Real-Time PCR for Profiling GST Expression}

Total RNA was extracted from frozen fresh leaves using a modified CTAB method and treated with RNase-free DNase I (Takara, Dalian, China) to remove genomic DNA contamination. 
The NanoPhotometer ${ }^{\circledR}$ spectrophotometer (IMPLEN, Westlake Village, CA, USA) was used to check RNA purity. Quantitative real-time PCR was used to determine one selected GST gene. These reactions were performed on the CFX96 Real-Time System C1000 Thermal Cycler (Bio-RAD, Hercules, CA, USA), following manufacturer protocol in a SYBR Premix Ex Taq kit (TaKaRa, Dalian, China), and analyzed with $2^{-\Delta \Delta C T}$. Relative gene expression was normalized with kiwifruit Actin1 and Actin2 [64]. Table 1 contains the primer sequences used for PCR. Three replicates were performed for three separate RNA extracts from three samples.

Table 1. qRT-PCR primer sequences.

\begin{tabular}{ccc}
\hline Gene Locus & Forward Primer & Reverse Primer \\
\hline ACHN160841 & GGTGTTGATACATAACGGAAAG & TGGACAATGATGAGGGACT \\
Actin1 & GCAGGAATCCATGAGACTACC & GTCTGCGATACCAGGGAACAT \\
\hline
\end{tabular}

\subsection{Expression Analysis of GST Genes Based on Transcriptome Data}

Six cDNA libraries were constructed for three $8 \mathrm{~h}$ treatments (CK, HT, and MTHT), each with two biological replicates. Sequencing libraries were generated using the NEBNext Ultra RNA Library Prep Kit for Illumina (NEB, Ipswich, MA, USA) and sequenced on an Illumina Hiseq 2000 platform. Paired-end reads (150 bp) were generated by Novogene (Beijing, China).

Reads numbers mapped to each gene were counted in HTSeq version 0.6.1. The FPKM per gene was calculated based on gene length and read count. Differential expression analysis of two biological replicates was performed in $\mathrm{R}$ with the DESeq package (version 1.18.0, European Molecular Biology Laboratory, Heidelberg, Germany). The resultant P-values were adjusted using the Benjamini-Hochberg procedure for controlling false discovery rate [65]. Adjusted $p<0.05$ was considered significant differential expression.

Acknowledgments: This work was financially supported by the Sichuan Science and Technology Project Program (2016NZ0105, 2017JY0054).

Author Contributions: Dong Liang, Fan Gao and Hui Xia conceived the idea and designed the research; Dong Liang, Fan Gao, Zhiyou Ni, Lijin Lin, Qunxian Deng, Yi Tang, Xun Wang, Xian Luo performed the experiments and analyzed the data; Hui Xia supervised the study; Dong Liang and Fan Gao wrote the manuscript with contributions from other coauthors.

Conflicts of Interest: The authors declare no conflict of interest.

\section{References}

1. Rodriguez, V.M.; Soengas, P.; Alonso-Villaverde, V.; Sotelo, T.; Cartea, M.E.; Velasco, M.P. Effect of temperature stress on the early vegetative development of Brassica oleracea L. BMC Plant Biol. 2015, 15, 145. [CrossRef] [PubMed]

2. Shah, F.; Huang, J.; Cui, K.; Nie, L.; Shah, T.; Chen, C.; Wang, K. Impact of high temperature stress on rice plant and its traits related to tolerance. J. Agric. Sci. 2011, 149, 545-556. [CrossRef]

3. Vasseur, F.; Pantin, F.; Vile, D. Changes in light intensity reveal a major role for carbon balance in Arabidopsis responses to high temperature. Plant Cell Environ. 2011, 34, 1563-1576. [CrossRef] [PubMed]

4. Mishkind, M.; Vermeer, J.E.; Darwish, E.; Munnik, T. Heat stress activates phospholipase D and triggers PIP accumulation at the plasma membrane and nucleus. Plant J. 2009, 60, 10-21. [CrossRef] [PubMed]

5. Narayanan, S.; Tamura, P.J.; Roth, M.R.; Prasad, P.V.; Welti, R. Wheat leaf lipids during heat stress, high day and night temperatures result in major lipid alterations. Plant Cell Environ. 2016, 39, 787-803. [CrossRef] [PubMed]

6. Mittler, R.; Vanderauwera, S.; Suzuki, N.; Miller, G.; Tognetti, V.B.; Vandepoele, K.; Gollery, M.; Shulaev, V.; Van Breusegem, F. ROS signaling, the new wave? Trends Plant Sci. 2011, 16, 300-309. [CrossRef] [PubMed]

7. Allakhverdiev, S.I.; Kreslavski, V.D.; Klimov, V.V.; Los, D.A.; Carpentier, R.; Mohanty, P. Heat stress, an overview of molecular responses in photosynthesis. Photosynth. Res. 2008, 98, 541-550. [CrossRef] [PubMed] 
8. Hasanuzzaman, M.; Nahar, K.; Alam, M.M.; Roychowdhury, R.; Fujita, M. Physiological, biochemical, and molecular mechanisms of heat stress tolerance in plants. Int. J. Mol. Sci. 2013, 14, 9643-9684. [CrossRef] [PubMed]

9. Dixon, D.P.; Davis, B.G.; Edwards, R. Functional divergence in the glutathione transferase superfamily in plants. Identification of two classes with putative functions in redox homeostasis in Arabidopsis thaliana. J. Biol. Chem. 2002, 277, 30859-30869. [CrossRef] [PubMed]

10. Moons, A. Regulatory and Functional Interactions of Plant Growth Regulators and Plant Glutathione S-Transferases (GSTs). Vitam. Horm. 2005, 72, 155-202. [CrossRef] [PubMed]

11. Arnao, M.B.; Hernández-Ruiz, J. Functions of melatonin in plants, a review. J. Pineal Res. 2015, 59, $133-150$. [CrossRef] [PubMed]

12. Fan, J.; Hu, Z.; Xie, Y.; Chan, Z.; Chen, Z.; Amombo, E.; Chen, L.; Fu, J. Alleviation of cold damage to photosystem II and metabolisms by melatonin in Bermudagrass. Front. Plant Sci. 2015, 6, 925. [CrossRef] [PubMed]

13. Zhang, J.; Shi, Y.; Zhang, X.Z.; Du, H.M.; Bin, X.; Bingru, H. Melatonin suppression of heat-induced leaf senescence involves changes in abscisic acid and cytokinin biosynthesis and signaling pathways in perennial ryegrass (Lolium perenne, L.). Environ. Exp. Bot. 2017, 138, 36-54. [CrossRef]

14. Tiryaki, I.; Keles, H. Reversal of the inhibitory effect of light and high temperature on germination of Phacelia tanacetifolia seeds by melatonin. J. Pineal Res. 2012, 52, 332-339. [CrossRef] [PubMed]

15. Marta, B.; Szafrańska, K.; Posmyk, M.M. Exogenous melatonin improves antioxidant defense in cucumber seeds (Cucumis sativus L.) germinated under chilling stress. Front. Plant Sci. 2016, 7, 575. [CrossRef] [PubMed]

16. Korkmaz, A.; Karaca, A.; Kocaçinar, F.; Cuci, Y. The effects of seed treatment with melatonin on germination and emergence performance of pepper seeds under chilling stress. Tarim Bilimleri Dergisi J. Agric. Sci. 2017, 23, 167-176.

17. Zhang, R.; Sun, Y.; Liu, Z.; Jin, W.; Sun, Y. Effects of melatonin on seedling growth, mineral nutrition, and nitrogen metabolism in cucumber under nitrate stress. J. Pineal Res. 2017, 62. [CrossRef] [PubMed]

18. Arnao, M.B.; Hernández-Ruiz, J. Melatonin promotes adventitious- and lateral root regeneration in etiolated hypocotyls of Lupinus albus L. J. Pineal Res. 2007, 42, 147-152. [CrossRef] [PubMed]

19. Laing, W.A. Temperature and light response curves for photosynthesis in kiwifruit (Actinidia chinensis) cv. Hayward. N. Z. J. Agric. Res. 1985, 28, 117-124. [CrossRef]

20. Richardson, A.C.; Marsh, K.B.; Boldingh, H.L.; Pickering, A.H.; Bulley, S.M.; Frearson, N.J.; Ferguson, A.R.; Thornber, S.E.; Bolitho, K.M.; Macrae, E.A. High growing temperatures reduce fruit carbohydrate and vitamin C in kiwifruit. Plant Cell Environ. 2004, 27, 423-435. [CrossRef]

21. Greer, D.H.; Laing, W.A.; Kipnis, T. Photoinhibition of photosynthesis in intact kiwifruit (Actinidia deliciosa) leaves, Effect of temperature. Planta 1988, 174, 152-158. [CrossRef] [PubMed]

22. Luo, H.T.; Zhang, J.Y.; Wang, G. Functional characterization of waterlogging and heat stresses tolerance gene Pyruvate decarboxylase 2 from Actinidia deliciosa. Int. J. Mol. Sci. 2017, 18, 2377. [CrossRef] [PubMed]

23. Li, H.; He, J.; Yang, X.; Li, X.; Luo, D.; Wei, C.; Ma, J.; Zhang, Y.; Yang, J.; Zhang, X. Glutathione-dependent induction of local and systemic defense against oxidative stress by exogenous melatonin in cucumber (Cucumis sativus L.). J. Pineal Res. 2016, 60, 206-216. [CrossRef] [PubMed]

24. Pieri, C.; Marra, M.; Moroni, F.; Recchioni, R.; Marcheselli, F. Melatonin, A peroxyl radical scavenger more effective than vitamin E. Life Sci. 1994, 55, 271-276. [CrossRef]

25. Tan, D.X.; Chen, L.D.; Poeggeler, B.; Manchester, L.D.; Reiter, R.J. Melatonin, a potent, endogenous hydroxyl radical scavenger. Endocr. J. 1993, 1, 57-60.

26. Tan, D.X.; Poeggeler, B.; Reiter, R.J. The pineal hormone melatonin inhibits DNA adduct formation induced by the chemical carcinogen safrole in vivo. Cancer Lett. 1993, 70, 65-71. [CrossRef]

27. Shi, H.; Wang, X.; Tan, D.X.; Reiter, R.J.; Chan, Z. Comparative physiological and proteomic analyses reveal the actions of melatonin in the reduction of oxidative stress in Bermuda grass (Cynodon dactylon (L). Pers.). J. Pineal Res. 2015, 59, 120-131. [CrossRef] [PubMed]

28. Li, C.; Tan, D.X.; Liang, D.; Chang, C.; Jia, D.F.; Ma, F.W. Melatonin mediates the regulation of ABA metabolism, free-radical scavenging, and stomatal behaviour in two malus species under drought stress. J. Exp. Bot. 2015, 66, 669-680. [CrossRef] [PubMed] 
29. Zhao, H.; Ye, L.; Wang, Y.; Zhou, X.T.; Yang, J.W.; Wang, J.W.; Cao, K.; Zou, Z. Melatonin Increases the Chilling Tolerance of Chloroplast in Cucumber Seedlings by regulating photosynthetic electron flux and the ascorbate-glutathione cycle. Front. Plant Sci. 2016, 7, 1814. [CrossRef] [PubMed]

30. Srinivasa-Rao, N.K.; Shivashankara, K.S.; Laxman, R.H. Abiotic Stress Physiology of Horticultural Crops; Springer: Berlin/Heidelberg, Germany, 2016.

31. Mittler, R. Oxidative stress, antioxidants and stress tolerance. Trends Plant Sci. 2002, 7, 405-410. [CrossRef]

32. Li, X.; Wei, J.P.; Scott, E.R.; Liu, J.W.; Guo, S.; Li, Y.; Zhang, L.; Han, W.Y. Exogenous Melatonin Alleviates Cold Stress by Promoting Antioxidant Defense and Redox Homeostasis in Camellia sinensis L. Molecules 2018, 23, 165. [CrossRef] [PubMed]

33. Li, X.N.; Brestic, M.; Tan, D.X.; Zivcak, M.; Zhu, X.C.; Liu, S.Q.; Song, F.B.; Reiter, R.J.; Liu, F.L. Melatonin alleviates low PS I-limited carbon assimilation under elevated $\mathrm{CO}_{2}$ and enhances the cold tolerance of offspring in chlorophyll b-deficient mutant wheat. J. Pineal Res. 2018, 64, e12453. [CrossRef] [PubMed]

34. Wang, C.; Wen, D.; Sun, A.; Han, X.Y.; Zhang, J.B.; Wang, Z.J.; Yin, Y.P. Differential activity and expression of antioxidant enzymes and alteration in osmolyte accumulation under high temperature stress in wheat seedlings. J. Cereal Sci. 2014, 60, 653-659. [CrossRef]

35. Ahmed, J.U.; Hassan, M.A. Evaluation of seedling proline content of wheat genotypes in relation to heat tolerance. Bangladesh J. Bot. 2011, 40, 17-22. [CrossRef]

36. Boggess, S.F.; Stewart, C.R. The relationship between water stress induced proline accumulation and inhibition of protein synthesis in tobacco leaves. Plant Sci. Lett. 1980, 17, 245-252. [CrossRef]

37. Sarropoulou, V.; Dimassi-Theriou, K.; Therios, L.; Koukourekou-Petridou, M. Melatonin enhances root regeneration, photosynthetic pigments, biomass, total carbohydrates and proline content in the cherry rootstock PHL-C (Prunus avium $\times$ Prunus cerasus). Plant Physiol. Biochem. 2012, 61, 162-168. [CrossRef] [PubMed]

38. Ding, F.; Liu, B.; Zhang, S. Exogenous melatonin ameliorates cold-induced damage in tomato plants. Sci. Hortic. 2017, 219, 264-271. [CrossRef]

39. Turk, H.; Erdal, S.; Genisel, M.; Atici, O.; Demir, Y.; Yanmis, D. The regulatory effect of melatonin on physiological, biochemical and molecular parameters in cold-stressed wheat seedlings. Plant Growth Regul. 2014, 74, 139-152. [CrossRef]

40. Meng, J.F.; Xu, T.F.; Wang, Z.Z.; Fang, Y.L.; Xi, Z.M.; Zhang, Z.W. The ameliorative effects of exogenous melatonin on grape cuttings under water-deficient stress: Antioxidant metabolites, leaf anatomy, and chloroplast morphology. J. Pineal Res. 2014, 57, 200-212. [CrossRef] [PubMed]

41. Noctor, G.; Foyer, C.H. Ascorbate and glutathione, keeping active oxygen under control. Annu. Rev. Plant Physiol. Plant Mol. Biol. 1998, 49, 249-279. [CrossRef] [PubMed]

42. Bonnefont-Rousselot, D.; Collin, F.; Jore, D.; Gardèsalbert, M. Reaction mechanism of melatonin oxidation by reactive oxygen species in vitro. J. Pineal Res. 2011, 50, 328-335. [CrossRef] [PubMed]

43. Karam, E.A.; Maresca, V.; Sorbo, S.; Keramat, B.; Basile, A. Effects of triacontanol on ascorbate-glutathione cycle in Brassica napus L. exposed to cadmium-induced oxidative stress. Ecotoxicol. Environ. Saf. 2017, 144, 268-274. [CrossRef] [PubMed]

44. Dixon, D.P.; Adrian, L.; Robert, E. Plant glutathione transferases. Genome Biol. 2005, 401, 169-186.

45. Fujita, M.; Hossain, M.Z. Modulation of pumpkin glutathione S-transferases by aldehydes and related compounds. Plant Cell Physiol. 2003, 44, 481-490. [CrossRef] [PubMed]

46. Dean, J.D.; Goodwin, P.H.; Hsiang, T. Induction of glutathione S-transferase genes of nicotiana benthamiana following infection by colletotrichum destructivum and C. orbiculare and involvement of one in resistance. J. Exp. Bot. 2005, 56, 1525-1533. [CrossRef] [PubMed]

47. Gong, H.; Jiao, Y.; Hu, W.W.; Pua, E.C. Expression of glutathione-S-transferase and its role in plant growth and development in vivo and shoot morphogenesis in vitro. Plant Mol. Biol. 2005, 57, 53-66. [CrossRef] [PubMed]

48. Kunieda, T.; Fujiwara, T.; Amano, T.; Shioi, Y. Molecular Cloning and characterization of a senescence-induced Tau-class glutathione S-transferase from barley leaves. Plant Cell Physiol. 2005, 46, 1540-1548. [CrossRef] [PubMed]

49. Urbanek, H.; Majorowicz, H.; Zalewski, M.; Saniewski, M. Induction of glutathione S-transferase and glutathione by toxic compounds and elicitors in reed canary grass. Biotechnol. Lett. 2005, 27, 911-914. [CrossRef] [PubMed]

50. Wagner, U.; Edwards, R.; Dixon, D.P.; Mauch, F. Probing the diversity of the Arabidopsis glutathione S-transferase gene family. Plant Mol. Biol. 2002, 49, 515-532. [CrossRef] [PubMed] 
51. Le, M.B.; Poage, M.; Shiel, K.; Nugent, G.D.; Dix, P.J. Tobacco chloroplast transformants expressing genes encoding dehydroascorbate reductase, glutathione reductase, and glutathione-S-transferase, exhibit altered anti-oxidant metabolism and improved abiotic stress tolerance. Plant Biotechnol. J. 2011, 9, 661-673. [CrossRef]

52. Xu, J.; Tian, Y.S.; Xing, X.J.; Peng, R.H.; Zhu, B.; Gao, J.J.; Yao, Q.H. Over-expression of AtGSTU19 provides tolerance to salt, drought and methyl viologen stresses in Arabidopsis. Physiol. Plant. 2015. [CrossRef]

53. Anwar, M.M.; Meki, A.R. Oxidative stress in streptozotocin-induced diabetic rats: Effects of garlic oil and melatonin. Comp. Biochem. Physiol. Part A Mol. Integr. Physiol. 2003, 135, 539-547. [CrossRef]

54. Reiter, R.J.; Tan, D.X. Melatonin: An antioxidant in edible plants. Ann. N. Y. Acad. Sci. USA 2002, 957, 341-344. [CrossRef]

55. Sergiev, L.; Alexieva, V.; Karanova, E. Effect of spermine, atrazine and combination between them on some endogenous protective systems and stress markers in plants. C. R. Acad. Bulg. Sci. 1997, 51, 121-124.

56. Bates, L.S.; Waldeen, R.P.; Teare, I.D. Rapid determination of free proline for water stress studies. Plant Soil 1973, 39, 205-207. [CrossRef]

57. Giannopolitis, C.N.; Ries, S.K. Superoxide Dismutases, II. purification and quantitative relationship with water-soluble protein in seedlings. Plant Physiol. 1977, 59, 315-318. [CrossRef] [PubMed]

58. Scebba, F.; Sebastiani, L.; Vitagliano, C. Activities of antioxidant enzymes during senescence of Prunus Armeniaca leaves. Biol. Plant. 2001, 44, 41-46. [CrossRef]

59. Patra, H.K.; Kar, M.; Mishra, D. Catalase activity in leaves and cotyledons during plant development and senescence. Biochem. Physiol. Pflanz. 1978, 172, 385-390. [CrossRef]

60. Kampfenkel, K.; Montagu, M.C.; Inzè, D. Extraction and determination of ascorbate and dehydroascorbate from plant tissue. Anal. Biochem. 1995, 225, 165-167. [CrossRef] [PubMed]

61. Nakano, Y.; Asada, K. Hydrogen peroxide is scavenged by ascorbate-specific peroxidase in spinach chloroplasts. Plant Cell Physiol. 1981, 22, 867-880. [CrossRef]

62. Arrigoni, O.; Dipierro, S.; Borraccino, G. Ascorbate free radical reductase, a key enzyme of the ascorbic acid system. FEBS Lett. 1981, 125, 242-244. [CrossRef]

63. Edwards, E.A.; Rawsthorne, S.; Mullineux, P.M. Subcellular distribution of multiple forms of glutathione reductase in leaves of pea (Pisum sativum L.). Planta 1990, 180, 278-284. [CrossRef] [PubMed]

64. Ferradás, Y.; Rey, L.; Troncoso, O.M.; Rey, M.; González, M.V. Identification and validation of reference genes for accurate normalization of real-time quantitative PCR data in kiwifruit. Plant Physiol. Biochem. 2016, 102, 27-36. [CrossRef] [PubMed]

65. Benjamini, Y.; Hochberg, Y. Controlling the false discovery rate: A practical and 580 powerful approach to multiple testing. J. R. Stat. Soc. 1995, 57, 289-300. [CrossRef]

Sample Availability: Samples of the compounds are not available from the authors.

(C) 2018 by the authors. Licensee MDPI, Basel, Switzerland. This article is an open access article distributed under the terms and conditions of the Creative Commons Attribution (CC BY) license (http:/ / creativecommons.org/licenses/by/4.0/). 